\title{
Appinite suites and their genetic relationship with coeval voluminous granitoid batholiths
}

\author{
J. Brendan Murphy (bmurphy@stfx.ca) \\ ${ }^{1}$ Department of Earth Sciences, St. Francis Xavier University, Antigonish, Nova Scotia, Canada, B2G 2W5
}

Although a plethora of experimental and theoretical studies have examined the role of water in silicic magma evolution, field-based investigations of appinite suites, which preserve visible evidence of the role of water in magma evolution under a range of natural conditions, are rarely integrated with these studies. The abundance of idiomorphic hornblende relative to olivine and pyroxene in rocks of mafic composition, the widespread development of mafic "pegmatites", together with the presence of "explosion-breccia pipes" indicate that appinitic mafic magmas are unusually abundant in $\mathrm{H}_{2} \mathrm{O}$. Appinites have been documented at deep to shallow crustal levels and range from Neo-Archean to Recent in age. Ultramafic-mafic members of the suite share common geochemical traits with shoshonites and whereas intermediate to felsic rocks compare favourably with high-Mg andesites, sanukitoids, tonalitetrondhjemite-granodiorite (TTG) suites and adakites. Many appinitic complexes are emplaced as relatively small coeval satellite bodies with respect to large, composite granitoid batholiths, and several studies imply a genetic relationship between their emplacement, the cessation of subduction, slab rollback and crustal growth.

Constraining the petrogenesis and tectonic affiliation of appinitic suites can not only provide insights into the behavior of water in silicic melts, it also can provide important clues to sources of orogenic and late-orogenic magmas including voluminous granitoid batholiths, aid in understanding the tectonic evolution of ancient convergent plate margins, and yield insights into the origins of several enigmatic suites. 